\title{
Grain textural analysis across a range of glacial facies
}

\author{
A. Khatwa, J. K. Hart, A. J. Payne \\ Department of Geography, University of Southampton, Southampton SO17 1BJ, England
}

\begin{abstract}
A technique proposed by Hooke and Iverson (1995) to identify deformed subglacial sediments is reviewed and tested, based on two main objectives. First, an investigation of whether the fractal dimension can distinguish between non-deformed and deformed facies; for which we compare supraglacial and subglacial facies explicitly. Second, an evaluation of whether the fractal dimension can be used as a diagnostic criteria to discriminate between different styles and degrees of basal deformation. This is tested using a range of sediments from the deformation continuum suggested by Hart and Boulton (1991b). Sixteen subglacial samples were selected from Quaternary sites in England and three supraglacial samples from the modern Haut Glacier d'Arolla, Switzerland. The mean fractal dimension for the subglacial diamicton matrix facies was 2.92, similar to findings of 2.90 by Hooke and Iverson (1995) for their basal tills. The supraglacial facies displayed a mean fractal dimension of 2.83, which is unusually high for facies which are assumed to be undeformed. A Mann-Whitney U test showed that fractal dimensions of supraglacial and subglacial diamicton matrix facies were not significantly different. No significant difference was found between the fractal dimensions of the different tectonic facies within the subglacial group. It may be impossible to separate the subglacial and supraglacial facies because of complex debris paths within the glacier. Grain fracture or parent lithology may affect the particle-size distribution of subglacial facies.
\end{abstract}

\section{INTRODUCTION}

Recent work has suggested that as a glacier moves over a saturated, unconsolidated stratum, shear stresses exerted by the glacier can exceed the shear strength of the sediment, initiating deformation (Boulton and Jones, 1979; Alley and others, 1987; Clarke, 1987). This process is termed subglacial deformation and has been described in relation to Quaternary deposits (Clark, 1991; Hart and Boulton, 1991b; Hicock and Dreimanis, 1992; Hart, 1994; Hart and Roberts, 1994) and also beneath contemporary glaciers such as Breiðamerkurjökull in Iceland (Boulton and Jones, 1979), Ice Stream B in western Antarctica (Alley and others, 1986; Englehardt and others, 1990) and Trapridge Glacier in Canada (Blake and Clarke, 1989). An extensive set of features has been associated with deforming-bed sediments including tectonic laminations, boudins and augens, folds, sharp basal décollement surfaces, predictable till fabrics, characteristic micromorphologies and boulder pavements (Dowdeswell and Sharp, 1986; Hart and others, 1990; Clark, 1991; Hart and Boulton, 1991b; Hicock, 1991; Van der Meer, 1993; Hart and Roberts, 1994; Hart, 1998). Although it is possible to use such features to identify subglacial deposits, further criteria are needed to support interpretations. The need for unequivocal criteria to distinguish subglacial facies from other deposits has been highlighted by Hart and Roberts (1994) and Van der Meer $(1993,1997)$. In these cases, micromorphology has revealed new insights into the internal grain structure and behaviour of deforming bed tills.

Hooke and Iverson (1995) and Iverson and others (1996) propose a technique for facies analysis which uses fractal dimension of grain-size distributions to interpret styles and degrees of deformation in glacial sediments. Fractal dimen- sion has been shown to be a useful interpretative tool in other areas of geology where highly deformed sediments exhibit self-similar grain-size distributions (Turcotte, 1986; Biegel and others, 1989; Brosch and others, 1992). Sammis and others (1987) carried out a detailed investigation of the grain-size distributions of fault breccia and concluded that the probability of fracture of any particle is independent of scale and after many fracture events a lognormal distribution of particle sizes results (Epstein, 1949). The theoretical fractal dimension of a fracture-dominated facies is 2.58 (Sammis and others, 1987). The investigation of grain crushing has subsequently been applied in a variety of other environments, such as geotechnical shear planes (Brosch and others, 1992), granular sediments (Mandl and others, 1977) and debris-rich basal ice (Hubbard and others, 1996).

Hooke and Iverson (1995) suggest that high fractal dimensions in basal tills could be attributed to grain slippage and abrasion over grain fracture during deformation. Supplementary evidence to support this argument comes from scanning-electron-microscope photographs of rounded grains (from a basal till) exhibiting fracture surfaces. The workers suggest that with further studies, it may be possible to use grain-size distributions expressed as fractal dimensions to distinguish between tills that have undergone deformation and those that have not. In the double-log plots presented by Hooke and Iverson (1995), the basal tills exhibit a clearer linear relationship than the non-deformed sediments (outwash and dune facies). These two arguments imply that the fractal dimension can be used as a diagnostic criteria for interpreting deformed and non-deformed sediments.

In this paper, we will use the technique proposed by Hooke and Iverson (1995) to address two main objectives:

(1) To investigate whether the fractal dimension can distin- 
guish between non-deformed and deformed facies, comparing supraglacial and subglacial facies explicitly; and

(2) To evaluate whether the fractal dimension can be used as a diagnostic criterion to discriminate between different styles and degrees of basal deformation. This is tested using a range of sediments from the deforming continuum suggested by Hart and Boulton (1991b).

Only one contemporary glacier (the Haut Glacier d'Arolla, Vallais, Switzerland) was used in our study to collect the supraglacial facies (due to logistical and time constraints). Collection of unequivocal subglacial sediments from contemporary glaciers is difficult and the techniques being developed to directly access this environment (Blake and others, 1992; Iverson and others, 1994) were not available during this study. For the purpose of this study, subglacial sediments interpreted to be deformed during the Quaternary were collected in England (Hart and Boulton, 1991a, b; Rose, 1991).

\section{APPLIGATION OF FRAGTALS TO DEFORMED SEDIMENTS}

The process of grain-crushing has been widely investigated in both cataclastic geology (Mandl and others, 1977; Sammis and others, 1987; Biegel and others, 1989) and glacial sediments (Boulton and others, 1974; Haldorsen, 1981; Hooke and Iverson, 1995; Iverson and others, 1996). Geological studies have focused on the process of structural faulting at shallow depths in the Earth's crust, which causes rock to brecciate into a sediment termed fault breccia. The fault breccia is formed by the repeated fracture of grains, which eventually leads to a grain-size distribution in which the number of equal-sized particles is minimized over a wide range of scales. Sammis and others (1987) argue that the highest intergranular stresses occur when two grains of identical size are in contact with one another. In this case, one of the particles is likely to break allowing a grain-size distribution to evolve which separates similar-sized grains. This spatial organization of grains produces a uniform distribution of stresses which minimizes stress concentrations. As a consequence, the fault breccia exhibits a self-similar (or fractal) grain-size distribution (Sammis and others, 1987). The fractal dimension for fault breccia calculated by these workers was 2.58 .

Hooke and Iverson (1995) applied this theory to deformed glacial sediments. Within a subglacial environment, shear stresses are imposed on a basal layer of till. The granular material exhibits a resistance to shear through the formation of grain bridges which support a compressive stress. The failure of these grain bridges may take one of two forms, fracture or slippage. Hooke and Iverson (1995) suggest that because a subglacial till is vertically constrained beneath the ice mass, dilation is inhibited and grain fracture becomes an important mechanism for grain-bridge failure. Tests carried out on deforming granular sediments in a ring shear apparatus have demonstrated both of the mechanisms described above (Mandl and others, 1977; Biegel and others, 1989). Whether a bridge fails by slippage or fracture is dependant on the strength of the particles and the angle of interparticle slip. These factors in turn depend on the particle-size distribution and the packing geometry (Biegel and others, 1989).

Hooke and Iverson (1995) studied the grain-size distributions of three basal tills (Storglaciären, Sweden; Engabreen, Norway; Ice Stream B, Antarctica) and discovered that their fractal values yielded a mean value of $\sim 2.9$. This value is higher than the theoretical value (2.58) required to minimize stress concentrations, suggesting that the tills have a higher content of fines than can be explained by grain fracture alone. To explain this, Hooke and Iverson (1995) suggest that during failure by slippage, abrasion among grains produces finer particles. If fracture were the sole factor in the failure of bridges, two or more particles of roughly equal size would always result. Using evidence from photomicrographs of rounded grains (which do not display equally sized grain pairs), the workers suggest that slip failure is more important in deformation tills than in fault breccia.

\section{METHODOLOGY}

\section{Sample collection}

A range of sediment samples (Tables 1 and 2) were collected

Table 1. Range of supraglacial samples analysed from the Glacier d'Arolla

\begin{tabular}{lcclcl}
\hline Faciesclass & Locality & Code & Faciestype & Facies & Pathway \\
\hline & Bas & LAG & Moraine & Gravels & $\begin{array}{l}\text { Subglacial/ } \\
\text { supraglacial } \\
\text { Supra- } \\
\text { glacial }\end{array}$ \\
& Haut & UAG3 & Lateral moraine & Gravels & $\begin{array}{l}\text { Supraglacial } \\
\text { Gaut }\end{array}$ \\
& UAG40 & Glacier surface & Gravels & Supraglacial \\
\hline
\end{tabular}

from contemporary and Quaternary glacial environments, including diamictons which have been interpreted as subglacially deformed sediments and also sediments of supraglacial origin. These two facies groups are subject to varying degrees of deformation as they are transported through the glacial system and provide an excellent opportunity to test our two main objectives. Figure 1 illustrates the possible pathways of sediments through the glacier/subglacial system.

\section{Supraglacial samples}

Bulk samples of supraglacial samples were collected from the Glacier d'Arolla. The samples were selected on the assumption they had not been subject to deformational processes during transportation through the glacial system (Fig. 1).

\section{Subglacial samples}

\section{North Norfolk sites}

Samples interpreted to be subglacially deformed diamictons were collected from a Quaternary site in Norfolk, England (Hart and Boulton, 1991a, b). This site was ideal for our analysis as we could sample a range of deformed facies.

The facies collected reflect the range of deformation within a subglacial environment. Facies groups grade from subglacial diamictons, through to boudins and tectonic laminae, and finally to a sample from an unconsolidated fault breccia. The diamictons at West Runton and Trimingham display features characteristic of deformation such as sheath folds, boudins and augens (Hart and Boulton, 1991b; Hart and Roberts, 1994). These features are formed as a result of ductile deformation in the subglacial zone. Figure 1 
Table 2. Range of subglacial samples analysed from Norfolk and Cumbria. The selection of these facies reflects the deforming continuum as suggested by Hart and Boulton (1991b)

\begin{tabular}{|c|c|c|c|c|c|}
\hline Facies class & Locality & Code & Facies type & Facies code & Pathway \\
\hline & Widdale Side, Cumbria & WSS1 & Clay diamicton & Dfm & Subglacial \\
\hline & Widdale Side, Cumbria & WSS3 & Clay diamicton & Dfm & Subglacial \\
\hline & Widdale Side, Cumbria & WSL & Silty diamicton & Dfm & Subglacial \\
\hline Subglacial & Grisedale Beck, Cumbria & GDS1 & Clay diamicton & Df & Subglacial \\
\hline Diamicton & Grisedale Beck, Cumbria & GDS2 & Sandy diamicton & Ds & Subglacial \\
\hline \multirow[t]{4}{*}{ Matrix } & Grisedale Beck, Cumbria & GDL & Clay diamicton & Df & Subglacial \\
\hline & Trimingham, Norfolk & TCS6 & Sandy diamicton & $\mathrm{Ds}(\mathrm{s})$ & Subglacial \\
\hline & West Runton, Norfolk & WRPl & Clay diamicton & Df & Subglacial \\
\hline & West Runton, Norfolk & WRC3 & Sandy diamicton & Ds & Subglacial \\
\hline \multirow{4}{*}{ Boudins } & Widdale Side, Cumbria & WSS2 & Boudin & $\mathrm{S}$ & Passive subglacial \\
\hline & Trimingham, Norfolk & TCS4 & Boudin & $\mathrm{Fm}$ & Passive subglacial \\
\hline & West Runton, Norfolk & WRP2 & Boudin & $\mathrm{Fm}$ & Passive subglacial \\
\hline & West Runton, Norfolk & WRC4 & Boudin & $\mathrm{S}$ & Passive subglacial \\
\hline Tectonic & West Runton, Norfolk & WRP3 & Tectonic laminations & $\mathrm{Fm}$ & Subglacial \\
\hline Laminations & West Runton, Norfolk & WRC2 & Tectonic laminations & $\mathrm{Fl}$ & Subglacial \\
\hline Fault Breccia & Trimingham, Norfolk & TFB4 & Tectonic laminations & $\mathrm{Fm}$ & Proglacial deformation \\
\hline
\end{tabular}

Facies classification codes: $\mathrm{G}=$ gravels $(2-60 \mathrm{~mm}) ; \mathrm{Fm}=$ fine-grained massive unit; Gc = gravels, clast-supported; D = diamicton; Gm = gravels, matrix-supported; Dm = diamicton, matrix-supported; $\mathrm{S}=$ sands $(2-0.06 \mathrm{~mm})$; Ds $=$ diamicton, sand-dominated; $\mathrm{F}=$ fines $(<0.06 \mathrm{~mm})$; Df $=$ diamicton, finegrained; $\mathrm{Fl}$ = fine-grained laminate; $\mathrm{D}-(\mathrm{s})=$ diamicton sheared.

illustrates how preglacial sediments are folded into the diamicton to form boudins, which become attenuated to form laminations, and then homogenized into a diamicton. This process can be conceptualized as a deformation continuum and is reflected in the sample selection.

The sediments of northeast Norfolk contain a number of distinct tills of the Anglian (Elsterian) glaciation. At West Runton (WR) a series of samples (WRP1, WRC3) were collected from the laminated diamicton (grid reference 187434) and at Trimingham (TCS6, grid reference 275394). These sediments have been interpreted as deforming bed tills (Hart and Boulton, 1991a) deposited during the Anglian (Elsterian) glaciation. Additionally, a fault breccia produced by a proglacial thrust fault within the Cromer Ridge push moraine (Hart, 1990) was sampled (Fig. 2). Figure 2b shows a cross-section of sedimentological features across the Trimingham fault zone (TFB). This area of intense brittle deformation was sampled (TFBl-5) but only TFB 4 was deemed suitable for analysis.

\section{Drumlin sites}

Many researchers consider drumlins to be associated with the deforming bed (e.g. Boulton, 1987). In addition, Hart (1997) has argued that the internal structures of drumlins

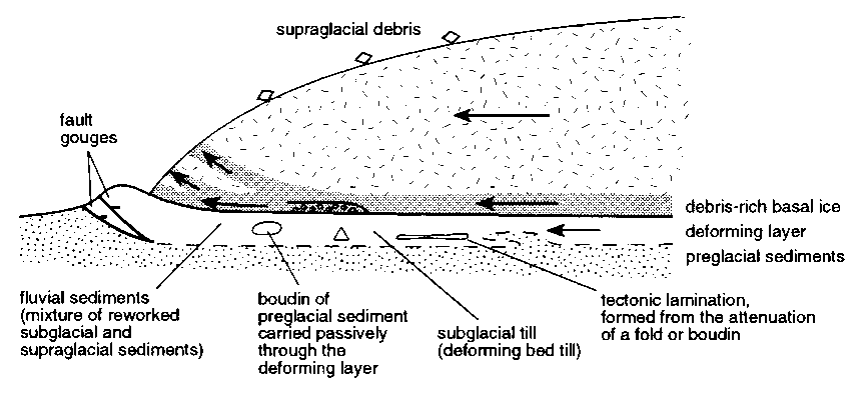

Fig. 1. Schematic diagram showing debris pathways through the glacier system. can be depositional, deformational or erosional depending on the relative competencies of material within the core and the deforming layer. Depositional drumlins will be composed of till deposited during the drumlinization process; deformational drumlins will show brittle or ductile deformation; and erosional drumlins will contain sediment that was not deformed/deposited during the drumlinizing event. Samples were taken from two drumlin sites: Widdale Side, North Yorkshire (grid reference 834886) and Grisedale Beck, Cumbria (grid reference 778923).

At Widdale Side, three samples were collected from the stoss side (WSS1-3) and a further sample was obtained towards the lee side (WSL). According to an interpretation by Rose (1991), the lowest unit in the Widdale Side succession is a strongly overconsolidated matrix-dominated diamicton. The matrix is composed of crushed mudstone with clasts exhibiting sub-angular to angular shapes. This particular unit has been interpreted as a subglacial till unit formed from local geology. The Grisedale Beck drumlin (grid reference 778923) was sampled in a similar fashion to Widdale Side; two samples were collected at the stoss side (GDS1-2) and a further one towards the lee (GDL).

\section{Calculation of fractal dimension}

The samples were mechanically sieved according to a method outlined by McManus (1988). Sediments sieved to under $125 \mu \mathrm{m}(3 \phi)$ were processed through a laser granulometer (LS Coulter counter). The combination of the two datasets assumed that particles were spherical, non-porous and of a constant density. Our grain-size classes ranged from $16.0 \mathrm{~mm}(-4 \phi)$ to $0.001 \mathrm{~mm}(10 \phi)$. In some cases data are absent from the coarse end of the grain-size spectrum.

The grain-size data allowed us to calculate the number of particles between the upper $\left(\mathrm{d}_{1}\right)$ and lower size class boundaries $\left(\mathrm{d}_{2}\right)$ of our grain-size range. These data yield $N$ (the number of particles), which are plotted logarith- 
(a)

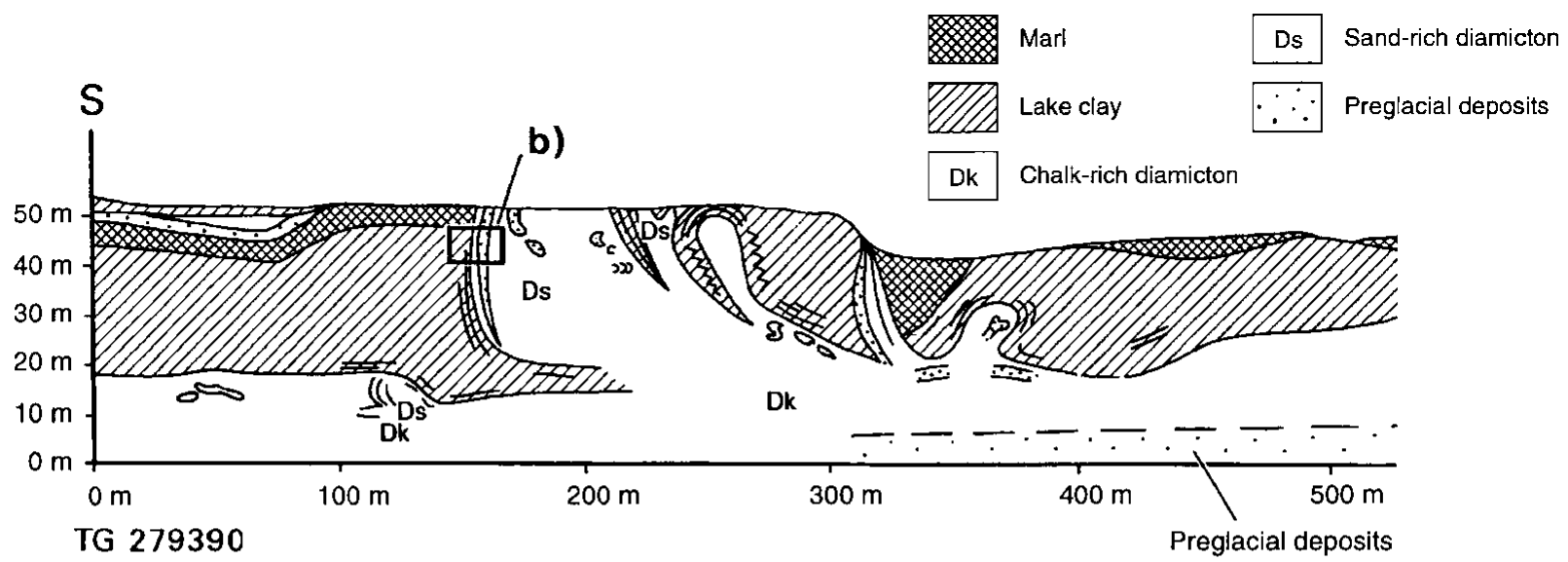

(b) Trimingham fault boundary (TFB)

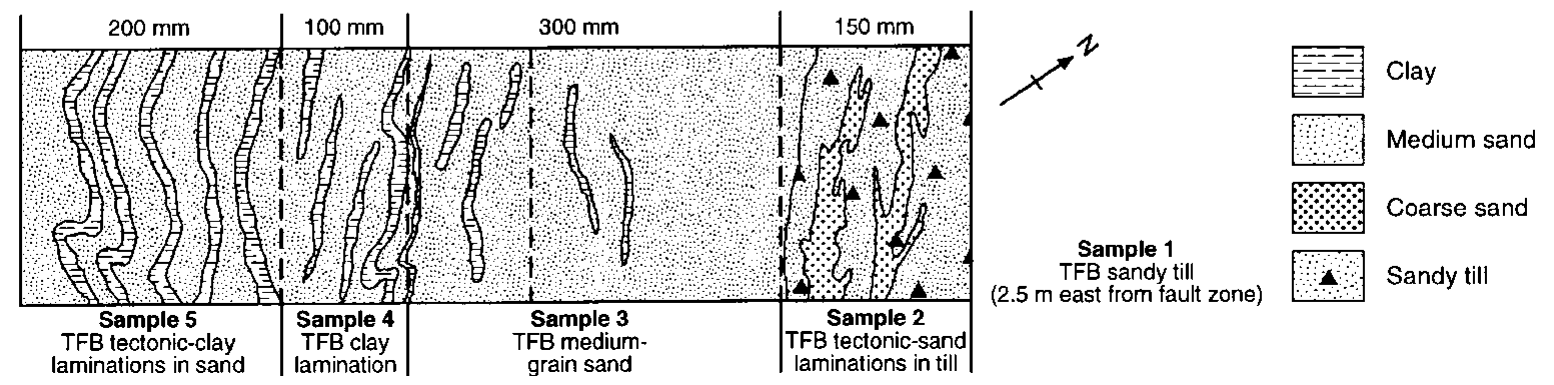

Fig. 2. Proglacial deformation at Trimingham: (a) large-scale section diagram of the listric thrust fault at the site (after Hart, 1990); ( b ) sedimentology along the fault breccia.

mically against particle diameter $(d)$. A linear relationship implies:

$$
N(d)=N_{0}\left(\frac{d}{d_{0}}\right)^{-m}
$$

where $N(d)$ is the number of particles of size $d, N_{0}$ is the number of particles of reference diameter $d_{0}$, and $m$ is the fractal dimension. A well-constrained linear relationship on such a plot can then be used to calculate $m$ (the fractal dimension or slope) using regression analysis, which reflects the ratio of smaller to larger particles over the size range analysed (Hubbard and others, 1996). The calculation of $N$ from $\mathrm{d}_{1}$ and $\mathrm{d}_{2}$ itself depends on the value of $m$. This means that the process must be iterated (Hooke and Iverson, 1995). Example plots are shown in Figures 3 and 4. Some plots display a slight displacement at the transition from Coulter counter data and sieve data. This transition does not affect our results significantly. Within our calculations, a bivariate slope-significance test was applied to the data (Williams, 1984).

\section{RESULTS}

\section{Supraglacial facies}

The data on this facies are summarized in Table 3. The double$\log$ plots for this facies can be seen in Figure 3. In summary, the three supraglacial samples collected from Haut Glacier d'Arolla have very similar values. The values display an average fractal dimension of 2.834 which is markedly higher than the value presented by Hubbard and others (1996) for a medial moraine facies at 2.50.

\section{Subglacial facies}

The data for this facies are summarized in Table 4. The double-log plots of these facies can be seen in Figure $4 \mathrm{a}-\mathrm{d}$.
LAC: (Slope 2.8, Correl. -0.996)

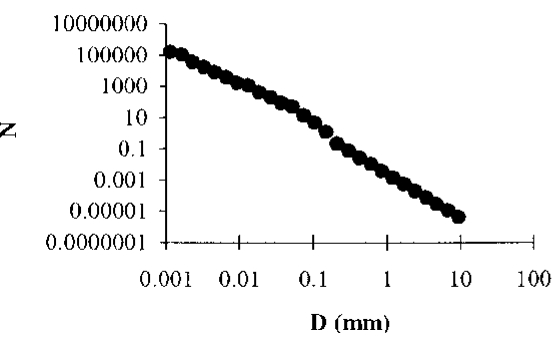

UAC.3 (Slope 2.89, Correl. - 0.991 )

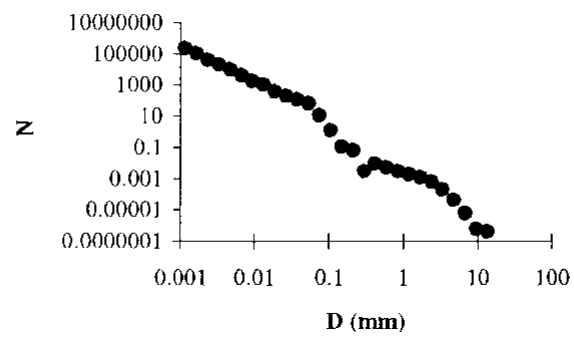

UAC;4 (Slope 2.80, Correl. -0.995)

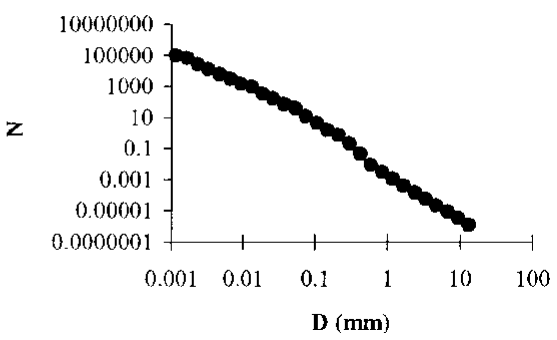

Fig. 3. Double-log plots of slope values for supraglacial facies comprising sieve and Coulter datasets ( $\mathcal{N}$ is the number of particles and $D$ is the particle diameter). The slope and correlation values are given on each graph. 


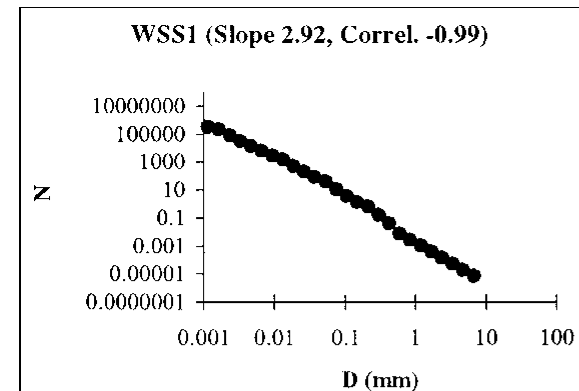

GDS1 (Slope 2.91, Correl. -0.99)

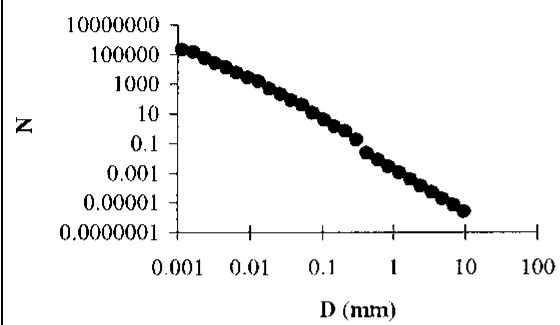

TCS6 (Slope 2.91, Correl. -0.99)

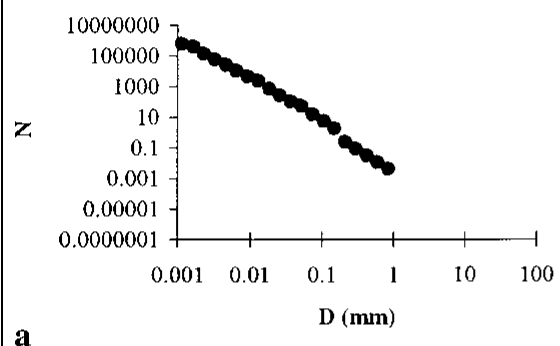

$\mathbf{a}$

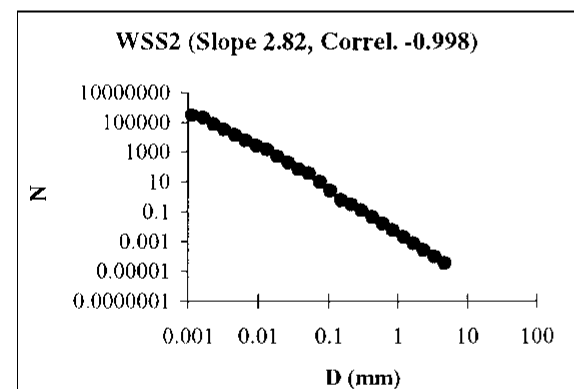

WRP2 (Slope 2.79, Correl. -0.994)

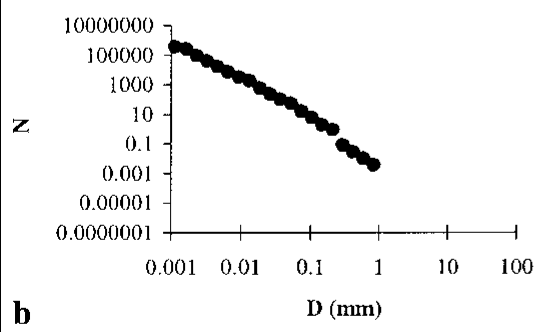

b

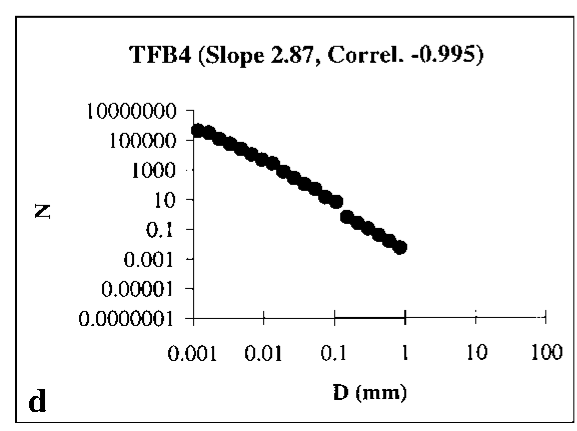

WSS3 (Slope 2.96, Correl. -0.99)

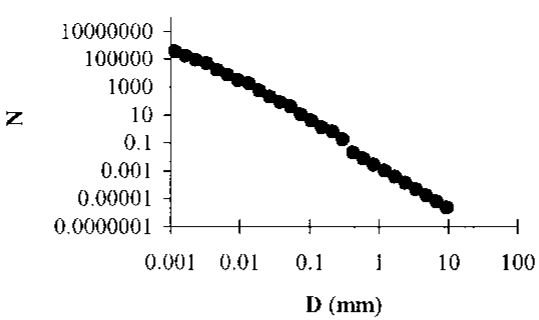

GDS2 (Slope 2.97, Correl. -0.99)

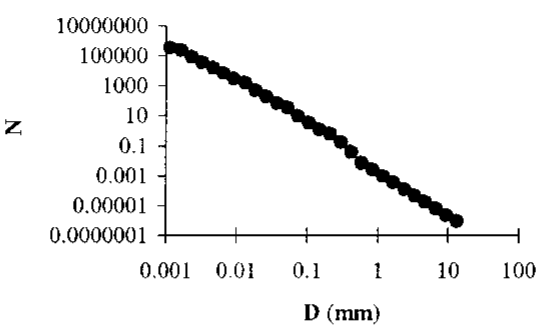

WRC3 (Slope 2.79, Correl. -0.99)
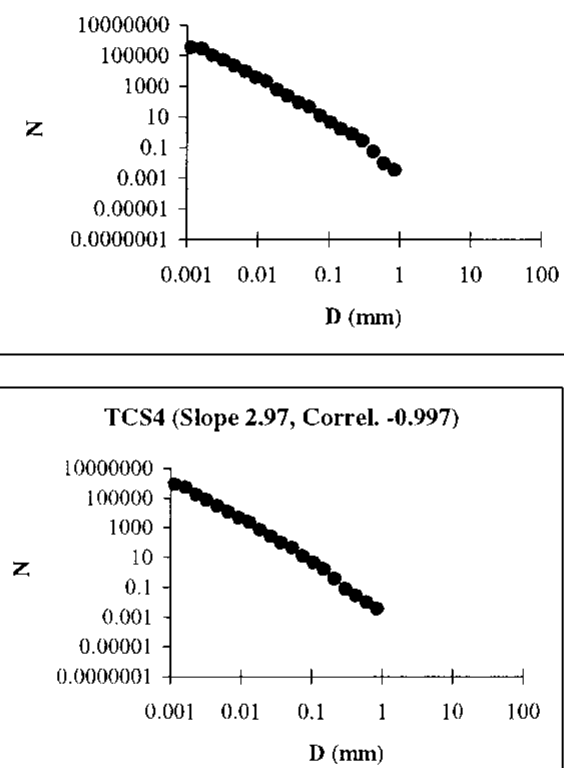

WRC4 (Slope 2.97, Correl. -0.997)

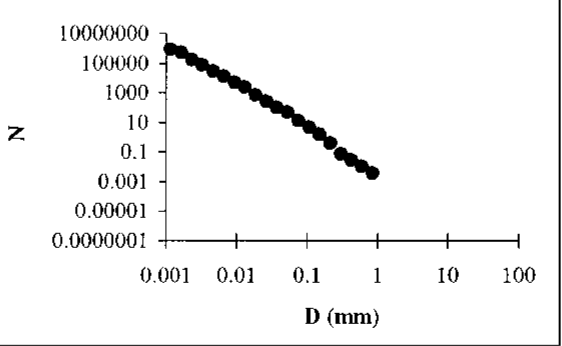

WSL (Slope 2.97, Correl. -0.99)

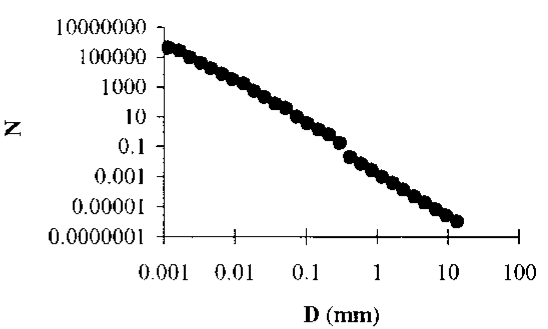

GDL (Slope 2.95, Correl. -0.99)

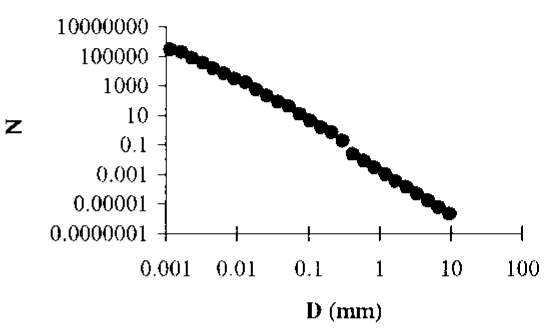

WRP1 (Slope 2.93, Correl. -0.99)
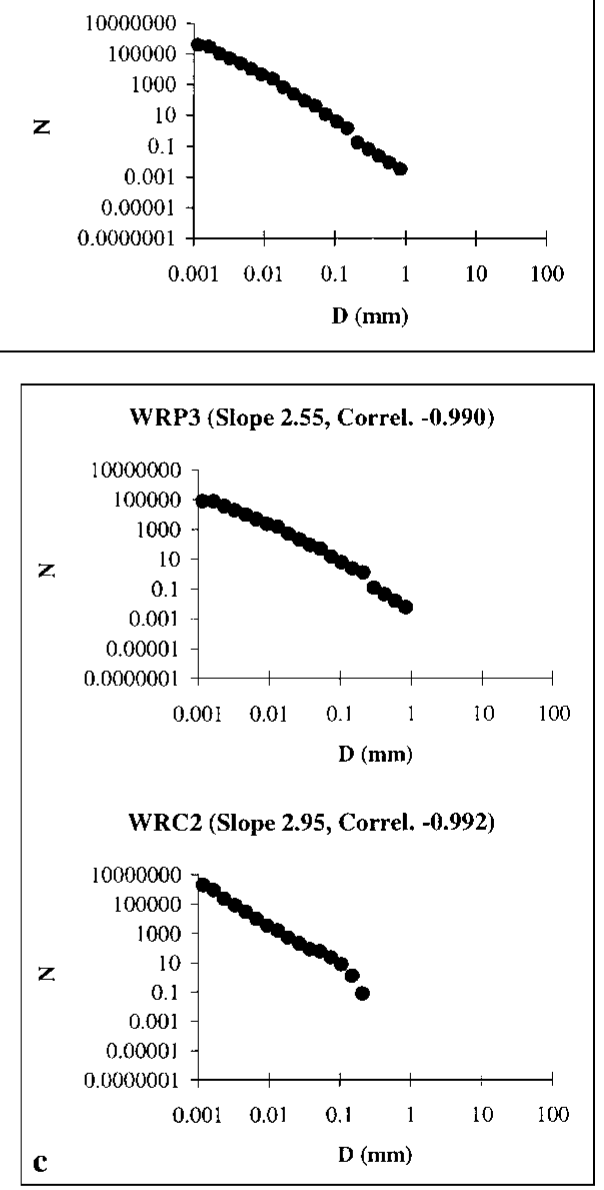

c

Fig. 4. Double-log plots for: (a) subglacial diamicton-matrix facies; (b) boudin facies; (c) tectonic-lamination facies; and (d) fault-breccia facies. Plots comprise sieve and Coulter datasets ( $\mathcal{N}$ is the number of particles and $D$ is the particle diameter). The slope and correlation values are given on each graph. 
Table 3. Fractal dimensions for the range of supraglacial samples analysed. The mean and standard deviation are presented. The values for these samples show little difference to the subglacial facies analysed

\begin{tabular}{lccccc}
\hline Facies class & Code & Value & $R$ & Mean & Std dev. \\
\hline \multirow{4}{*}{ Supraglacial } & LAG & 2.808 & -0.996 & 2.834 & 0.043 \\
& UAG3 & 2.895 & -0.991 & & \\
& UAG4 & 2.799 & -0.995 & & \\
\hline
\end{tabular}

Table 4. Fractal dimensions for the range of subglacial samples analysed. The mean and standard deviations are presented. The values do not significantly vary across the deforming continuum nor are they significantly greater than the supraglacial facies

\begin{tabular}{|c|c|c|c|c|c|}
\hline Facies class & Code & Value & $R$ & Mean & Std dev. \\
\hline $\begin{array}{l}\text { Subglacial } \\
\text { Diamicton } \\
\text { Matrix }\end{array}$ & $\begin{array}{c}\text { WSS1 } \\
\text { WSS3 } \\
\text { WSL } \\
\text { GDS1 } \\
\text { GDS2 } \\
\text { GDL } \\
\text { TCS6 } \\
\text { WRP1 } \\
\text { WRC3 }\end{array}$ & $\begin{array}{l}2.929 \\
2.975 \\
2.975 \\
2.914 \\
2.971 \\
2.951 \\
2.914 \\
2.931 \\
2.798\end{array}$ & $\begin{array}{l}0.997 \\
0.997 \\
0.998 \\
0.998 \\
0.996 \\
0.997 \\
0.996 \\
0.996 \\
0.995\end{array}$ & 2.929 & 0.052 \\
\hline Boudins & $\begin{array}{c}\text { WSS2 } \\
\text { TCS4 } \\
\text { WRP2 } \\
\text { WRC4 }\end{array}$ & $\begin{array}{l}2.828 \\
2.973 \\
2.793 \\
2.973\end{array}$ & $\begin{array}{l}0.997 \\
0.994 \\
0.997 \\
0.995\end{array}$ & 2.892 & 0.082 \\
\hline $\begin{array}{l}\text { Tectonic } \\
\text { Laminations }\end{array}$ & $\begin{array}{l}\text { WRP3 } \\
\text { WRC2 }\end{array}$ & $\begin{array}{l}2.558 \\
2.957\end{array}$ & $\begin{array}{l}0.992 \\
0.998\end{array}$ & 2.758 & 0.200 \\
\hline Fault Breccia & TFB4 & 2.872 & 0.995 & & \\
\hline
\end{tabular}

The fractal values for the subglacial facies display little variation across the facies boundaries. The subglacial diamicton-matrix facies exhibit a mean value of 2.92, which is very similar to the values found by Hooke and Iverson (1995) in their basal-till analysis. Boudins and tectonic-lamination facies display a mean value which is only slightly lower (but not significantly) than the subglacial diamictonmatrix facies. The fault-breccia facies yields a value of 2.87, which is very similar to the other facies in the group. A Mann-Whitney U test showed there was no significant difference between the supraglacial and the subglacial diamicton-matrix fractal-dimension values. Also, that there was no significant difference between the fractal dimensions of the various tectonic facies within the subglacial group. The Mann-Whitney U test results can be seen in Table 5 .

Table 5. Mann-Whitney $U$ test for unmatched samples: Significance results

\begin{tabular}{lll}
\hline Variablestested & $\begin{array}{c}\text { Probability } \\
\text { level }\end{array}$ & Interpretation \\
\hline Subglacial d.m. vs supraglacial & $\mathrm{P}>0.05$ & n.s.d. \\
Subglacial d.m. vs boudins & $\mathrm{P}>0.05$ & n.s.d. \\
Subglacial d.m. vs tectonic laminations & $\mathrm{P}>0.05$ & n.s.d. \\
\hline
\end{tabular}

d.m. = diamicton matrix; n.s.d. = no significant difference

\section{DISGUSSION}

All the subglacial samples suggest a strong tendency towards self-similarity, where the mean value across facies ranges from 2.7-2.9. Although these data support the suggestion by Hooke and Iverson (1995) that basal tills exhibit fractal behaviour, the technique cannot differentiate between the specific glacial facies tested. In this context, it is interesting to note that the supraglacial facies also have high fractal dimensions. We will attempt to explain the high values associated with this facies in the first part of the discussion. Later, we will examine the various problems involved in this type of analysis.

\section{Supraglacial facies: fractal or not?}

The supraglacial facies exhibit high fractal dimensions with a mean value of 2.834. Supraglacial debris may be transported through complex subglacial or englacial pathways on its journey to the snout of the glacier (Boulton, 1978). Therefore, facies collected in supraglacial locations on glaciers may have undergone deformation and abrasion on their passage through the glacier. This may account for the high fractal dimensions found for the supraglacial facies.

\section{Evaluation of the fractal-analysis technique}

Hooke and Iverson (1995) suggest that facies with fractal values yielding values of 2.9 have a higher content of fines, which can be attributed to grain slippage and abrasion rather than grain fracture. But are there other factors which may influence the amount of fines in a deforming sample just as strongly as grain behaviour?

Hooke and Iverson (1995) attribute the high fractal dimension of their basal tills to grain abrasion during slippage. However, fine-grained fractions may be inherited from parent lithology. An example of this is where Tulaczyk and others (1998) state that the clay-rich diamicton of Ice Stream $\mathrm{B}$ cores contained reworked diatoms and the fine-grained nature of the till inhibits glacial comminution because interparticle stress concentrations are cushioned. The origin of the sediment, therefore, not only contributes to the grain-size distribution, but it also affects grain behaviour. Additionally, erosive processes between the bedrock and the deforming bed may also generate fines, contributing to the grain-size distribution of the till.

This raises the question of whether the fractal value is a real indication of the significance of grain behaviour during deformation or just a method of evaluating the prominence of fines within the sediment. Further work is therefore needed to determine whether the fine-grained nature of deformed material is due to grain bridging or to lithological characteristics inherited from parent material. The potential importance of parent lithology brings into question the validity of comparing our data with samples tested by Hooke and Iverson (1995) and Hubbard and others (1996).

Evidence of grain bridging within field samples has yet to be investigated in detail, but Van der Meer $(1993,1997)$ has discussed the existing evidence for the behaviour of grains during deformation at length. From the extensive analysis of the micromorphology of deformed subglacial sediments, he proposes that particle movements within the matrix are rotational and that grains move freely through the till mass. The particle movement becomes more complex where the areas of the till are dominated by shear zones. Ro- 
tational structures are characterized by a nucleus composed of a grain or stiff matrix, surrounded by finer grains. The finer grains have been observed to spiral around the nucleus, which has been termed a galaxy structure (Van der Meer, 1997). Grain bridging in field samples has yet to be discovered and, until such evidence is found, grain rotation appears to be the dominant mechanism governing grain behaviour during deformation.

This process of grain rotation within deforming granular sediments could also be related to a feature observed in a deforming till at Cora Island, Spitsbergen (Boulton and others, 1989; Hart, 1995). The presence of a bivalve shell was observed undisturbed within a deformed till where the upper half of the shell was displaced over the lower half. Although this till was interpreted as having been deformed under low shear strains (Hart, 1995), in a grain-bridging environment the shell would not have survived in this condition. The shell may have behaved as a competent material, being transported as a whole, while the smaller grains in the matrix flowed (or rotated) around it.

\section{GONGLUSION}

The subglacial diamicton-matrix sediments exhibited a mean fractal dimension of 2.92 which compares favourably with findings by Hooke and Iverson (1995), who calculated an average value of 2.90 for their basal-till samples. However, the technique was unable to distinguish facies across a subglacial continuum ranging from boudins to subglacial diamicton matrix. Although fractal dimension is useful in identifying the tendency of basal tills to self-similarity, it is inconclusive when used to identify deformation across a range of facies.

\section{AGKNOWLEDGEMENTS}

The authors would like to thank B. P. Hubbard for his assistance with calculating the fractal-dimension values. Also, many thanks to T. Aspden and his colleagues at the Cartographic Unit, Department of Geography for their diagram preparation. A. K. was in receipt of a British Federation of Women Graduates grant CF/1 and a University studentship during the field research for this paper.

\section{REFERENCES}

Alley, R. B., D. D. Blankenship, C. R. Bentley and S. T. Rooney. 1986. Deformation of till beneath Ice Stream B, West Antarctica. Nature, 322(6074), 57-59.

Alley, R. B., D. D. Blankenship, C. R. Bentley and S. T. Rooney. 1987. Till beneath Ice Stream B. 3. Till deformation: evidence and implications. 7. Geophys. Res., 92(B9), 8921-8929.

Biegel, R. L., C. G. Sammis and J. Dieterich. 1989. The frictional properties of simulated gouge having a fractal particle size distribution. 7. Struct. Geol., $11(7), 827-846$.

Blake, E.W. and G. K. C. Clarke. 1989. In situ strain measurements beneath a surge-type glacier. [Abstract.] EOS, 70(43), 1084.

Blake, E., G. K. C. Clarke and M. C. Gérin. 1992. Tools for examining subglacial bed deformation. F. Glaciol., 38(130), 388-396.

Boulton, G. S. 1978. Boulder shapes and grain-size distributions of debris as indicators of transport paths through a glacier and till genesis. Sedimentology, 25(6), 773-799.

Boulton, G. S. 1987. A theory of drumlin formation by subglacial sediment deformation. In Menzies, J. and J. Rose, eds. Drumlin Symposium. Rotterdam, A.A. Balkema, 25-80.

Boulton, G. S. and A. S. Jones. 1979. Stability of temperate ice caps and ice sheets resting on beds of deformable sediment. F. Glaciol., 24(90), 29-43.

Boulton, G. S., D. L. Dent and E. M. Morris. 1974. Subglacial shearing and crushing, and the role of water pressures in tills from south-east Iceland. Geogr. Ann., 56A(3-4), 135-145.

Boulton, G. S. and 9 others. 1989. Preliminary report on Glaciotecs '84. Amsterdam. University of Amsterdam. Fysisch Geografisch en Bodemkundig Laboratorium. (Report.)

Brosch, F., P. Pölsler and G. Riedmüller. 1992. The use of fractal dimension in engineering geology. Bull. Int. Assoc. Eng. Geol., 45, 83-88.

Clark, P. U. 1991. Striated clast pavements: products of deforming subglacial sediment? Geology, 19(5), 530-533.

Clarke, G. K. C. 1987. Subglacial till: a physical framework for its properties and processes. 7. Geophys. Res., 92(B9), 9023-9036.

Dowdeswell, J. A. and M. J. Sharp. 1986. Characterization of pebble fabrics in modern terrestrial glacigenic sediments. Sedimentology, 33(5), 699-710.

Engelhardt, H., N. Humphrey, B. Kamb and M. Fahnestock. 1990. Physical conditions at the base of a fast moving Antarctic ice stream. Science, 248(4951), 57-59.

Epstein, B. 1949. The mathematical description of certain breakage mechanisms leading to the logarithmic-normal distribution. F. Franklin Inst., 244, 471-477.

Haldorsen, S. 1981. Grain-size distribution of subglacial till and its relation to glacial crushing and abrasion. Boreas, 10(1), 91-105.

Hart, J. K. 1990. Proglacial glaciotectonic deformation and the origin of the Cromer Ridge push moraine complex, north Norfolk, England. Boreas, 19(2), 165-180.

Hart, J. K. 1994. Till fabric associated with deformable beds. Earth Surf. Processes Landforms, 19(1), 15-32.

Hart, J. K. 1995. Subglacial erosion, deposition and deformation associated with deformable beds. Prog. Phys. Geogr., 19(2), 173-191.

Hart, J. K. 1997. The relationship between drumlins and other forms of subglacial glaciotectonic deformation. Quat. Sci. Rev., 16(1), 93-107.

Hart, J. K. 1998. The deforming bed/debris-rich basal ice continuum and its implications for the formation of glacial landforms (flutes) and sediments (melt-out till). Quat. Sci. Rev., 17, 737-754.

Hart, J. K. and G. S. Boulton. 1991a. The glacial geology of north east Norfolk. In Ehlers, J., P. L. Gibbard and J. Rose, eds. Glacial deposits in Great Britain and Ireland. Rotterdam, A.A. Balkema, 233-244.

Hart, J. K. and G. S. Boulton. 1991b. The interrelation of glaciotectonic and glaciodepositional processes within the glacial environment. Quat. Sci. Rev., 10(4), 335-350.

Hart, J. K. and D. H. Roberts. 1994. Criteria to distinguish between subglacial glaciotectonic and glaciomarine sedimentation: I. Deformation styles and sedimentology. Sediment. Geol., 91(1-4), 191-213.

Hart, J. K., R. C. A. Hindmarsh and G. S. Boulton. 1990. Different styles of subglacial glaciotectonic deformation within the context of the Anglian ice-sheet. Earth Surf. Processes Landforms, 15(3), 227-241.

Hicock, S. R. 1991. On subglacial stone pavements in till. f. Geol., 99(4), 607-619.

Hicock, S. R. and A. Dreimanis. 1992. Deformation till in the Great Lakes region: implications for rapid flow along the south-central margin of the Laurentide ice sheet. Can. 7. Earth Sci., 29(7), 1565-1579.

Hooke, R. LeB. and N. R. Iverson. 1995. Grain-size distribution in deforming subglacial tills: role of grain fracture. Geology, 23(1), 57-60.

Hubbard, B., M. Sharp and W. J. Lawson. 1996. On the sedimentological character of Alpine basal ice facies. Ann. Glaciol., 22, 187-193.

Iverson, N. R., P. Jansson and R. LeB. Hooke. 1994. In-situ measurement of the strength of deforming subglacial till. F. Glaciol., 40(136), 497-503.

Iverson, N. R., T. S. Hooyer and R. LeB. Hooke. 1996. A laboratory study of sediment deformation: stress heterogeneity and grain-size evolution. Ann. Glaciol., 22, 167-175.

Mandl, G., L. N. J. de Jong and A. Maltha. 1977. Shear zones in granular material - an experimental study of their structure and mechanical genesis. Rock Mech., 9, 95-144.

McManus, J. 1988. Grain size determination and interpretation. In Tucker, M. E., ed. Techniques in sedimentology. Oxford, Blackwell Science, 63-85.

Rose, J. 1991. Drumlin sediments, Widdale Side. In Mitchell, W., ed. Western Pennines field guide. London, Quaternary Research Association, 61-65.

Sammis, C., G. King and R. Biegel. 1987. The kinematics of gouge deformation. Pure Appl. Geophys., 125(5), 777-812.

Tulaczyk, S., B. Kamb, R. P. Scherer and H. F. Engelhardt. 1998. Sedimentary processes at the base of the West Antarctic ice stream: constraints from textural and compositional properties of subglacial debris. F. Sediment. Res., $68(3 \mathrm{~A}), 487-496$.

Turcotte, D. L. 1986. Fractals and fragmentation. 7. Geophys. Res., 91 (B2), 1921-1926.

Van der Meer, J.J. M. 1993. Microscopic evidence of subglacial deformation. Quat. Sci. Rev., 12(7), 553-587.

Van der Meer, J. J. M. 1997. Particle and aggregate mobility in till: microscopic evidence of subglacial processes. Quat. Sci. Rev., 16(8), 827-831.

Williams, R. B. G. 1984. Introduction to statistics. London, Macmillan. 